\title{
Digestive System Surgery
}

National Cancer Institute

\section{Source}

National Cancer Institute. Digestive System Surgery. NCI Thesaurus. Code C15330.

Surgery performed on any part of the digestive system. 